\title{
Why Strict Churches Are Strong ${ }^{1}$
}

\author{
Laurence R. Iannaccone \\ Santa Clara University
}

\begin{abstract}
The strength of strict churches is neither a historical coincidence nor a statistical artifact. Strictness makes organizations stronger and more attractive because it reduces free riding. It screens out members who lack commitment and stimulates participation among those who remain. Rational choice theory thus explains the success of sects, cults, and conservative denominations without recourse to assumptions of irrationality, abnormality, or misinformation. The theory also predicts differences between strict and lenient groups, distinguishes between effective and counterproductive demands, and demonstrates the need to adapt strict demands in response to social change.
\end{abstract}

In 1972 Dean Kelley published a remarkable book titled Why Conservative Churches Are Growing (Kelley 1986). In it he documented a striking shift in the fortunes of America's oldest and largest Protestant denominations. After two centuries of growth that culminated in the 1950s, virtually all mainline Protestant denominations had begun losing members. The losses, however, were far from uniform. Liberal denominations were declining much more rapidly than conservative denominations, and the most conservative were growing. The varying rates of growth and decline meant that the mainline denominations' misfortune could not be attributed to pervasive secularization. A valid explanation could only be rooted in traits or circumstances that differed from one denomination to the next. Kelley proposed such an explanation. He traced the success of conservative churches to their ability to attract and retain an active and committed membership, characteristics that he in turn attributed to their

\footnotetext{
${ }^{1}$ I presented early drafts of this paper at the meetings of the Society for the Scientific Study of Religion, Salt Lake City, Utah, October 1989, and of the Public Choice Society, Phoenix, March 1990, and at several department seminars. I thank many colleagues for their comments and suggestions, particularly Roger Finke, Benton Johnson, Dean Kelley, Darren Sherkat, James Spickard, Rodney Stark, William Swatos, and R. Stephen Warner. The work was supported in part by a grant from the Lilley Foundation. Address all correspondence to Laurence R. Iannaccone, Department of Economics, Santa Clara University, Santa Clara, California 95053.
}

(C) 1994 by The University of Chicago. All rights reserved.

0002-9602/94/9905-0002\$01.50 
strict demands for complete loyalty, unwavering belief, and rigid adherence to a distinctive lifestyle.

Twenty years have done nothing to weaken the force of Kelley's argument. The trends he identified continue unabated, so much so that "small sects" such as the Mormons and the Assemblies of God now outnumber "mainline" denominations such as the Episcopal Church and the United Church of Christ. Statistical studies have confirmed that denominational growth rates correlate strongly with "strictness" and its concomitants (Hoge 1979), and new historical research has revealed that the mainline's share of the churchgoing population has been declining since the American Revolution (Finke and Stark 1992).

Even so, many researchers question the causal role of strictness. They look to other factors to account for commitment, participation, and membership. Hoge and Roozen (1979), for example, have argued that observed membership trends are primarily the consequence of "contextual factors" such as birthrates and socioeconomic conditions, rather than "institutional factors" such as strictness.

In this article, I argue that Kelley was correct. In showing how strictness overcomes free-rider problems I embed Kelley's thesis within a much broader rational choice approach to religion. I have previously claimed that rational choice theory provides an alternative paradigm in the sociology of religion, one that unifies many of the generalizations that currently compete for researchers' attention (Iannaccone 1992a; see also Warner 1993). Here I provide a unified approach to the study of Protestant denominations, Jewish denominations, cults, communes, and church-sect theory.

Having claimed that Kelley was correct, I should emphasize two qualifications. First, both my article and Kelley's book address church growth only indirectly. The primary argument concerns how strictness increases commitment, raises levels of participation, and enables a group to offer more benefits to current and potential members. It seems obvious that such groups enjoy a competitive advantage over their opposites (who suffer from less commitment, lower participation, and fewer perceived benefits), but the mechanics of growth remains a separate subject (this is addressed more directly in Iannaccone, Stark, and Olson [1993]). ${ }^{2}$ Second, in modeling the benefits of strictness, I do not thereby assert that

\footnotetext{
${ }^{2}$ Kelley blamed his publisher for "insisting" on the misleading title, Why Conservative Churches Are Growing. In the preface to later editions, he emphasized that "the book is not primarily about 'conservative' churches-whatever they are!-or church growth. A more accurate title might be 'Why Strict Churches Are Strong'-whether 'liberal' or 'conservative,' whether 'growing' in membership at the moment or not" (1986, p. xvii; emphasis in original). For this article, I have adopted his preferred title in an effort to clarify my position and his.
} 
these benefits persist, no matter how strict a group becomes. To the contrary, both theory and data imply "optimal" levels of strictness, beyond which strictness discourages most people from joining or remaining within the group. I will address this issue in the article's final sections.

\section{RESTATING KELLEY'S THESIS}

How do we define strictness? Kelley (1986, pp. 79-84) cataloged three traits of the ideal-typical strict church-absolutism, conformity, and fanaticism-and contrasted them to three traits of the more lenient church-relativism, diversity, and dialogue. Strict churches proclaim an exclusive truth - a closed, comprehensive, and eternal doctrine. They demand adherence to a distinctive faith, morality, and lifestyle. They condemn deviance, shun dissenters, and repudiate the outside world. They frequently embrace "eccentric traits," such as distinctive diet, dress, or speech, that invite ridicule, isolation, and persecution.

For the purpose of formal analysis, I shall narrow this catalog to a single attribute: the degree to which a group limits and thereby increases the cost of nongroup activities, such as socializing with members of other churches or pursuing "secular" pastimes. This radical simplification allows us to model and test Kelley's thesis. It also accords with Kelley's (1986, p. xxii) own belief that church strength depends largely on a single characteristic which he alternately called "seriousness," "strictness," "costliness," and "bindingness."

A cost-based definition of strictness highlights the paradox in Kelley's thesis. After all, it is the essence of rationality to seek benefits and avoid costs. If strictness increases costs, why should anyone join a strict church? The religious marketplace teems with less demanding alternatives. Why become a Mormon or a Seventh Day Adventist, let alone a Krishna or a Moonie, when the Methodists and Presbyterians wait with open arms? Mormons abstain from caffeine and alcohol, Seventh Day Adventists avoid eating meat, Krishnas shave their heads, wear robes, and chant in public, Moonies submit to arranged marriages, Jehovah's Witnesses refuse transfusions, Orthodox Jews wear side curls and yarmulkes, conduct no business on the Sabbath, and observe numerous dietary restrictions, and monks take vows of celibacy, poverty, and silence. These practices are problematic, not only because they deviate from "normal" behavior, but also because they appear completely counterproductive. Pleasures are sacrificed, opportunities forgone, and social stigma is risked, or even invited. The problem is epitomized by the burnt offering, a religious rite designed specifically to destroy valuable resources. How can burnt offerings and their equivalents survive in religious markets when self-interest and competitive pressures drive them out of most other 
markets? As Kelley pointed out, the question is not merely one of survival; religious groups that demand such sacrifices are more successful than those that do not. ${ }^{3}$

I shall argue that strict demands "strengthen" a church in three ways: they raise overall levels of commitment, they increase average rates of participation, and they enhance the net benefits of membership. These strengths arise because strictness mitigates free-rider problems that otherwise lead to low levels of member commitment and participation. Free riders threaten most collective activities, and religious activities are no exception. Church members may attend services, call upon the pastor for counsel, enjoy the fellowship of their peers, and so forth, without ever putting a dollar in the plate or bringing a dish to the potluck. Direct monitoring (of attendance, contributions, and other overt behaviors) fails to solve the problem because it tends to undermine critical group attributes such as commitment, enthusiasm, and solidarity. But seemingly unproductive costs provide an indirect solution. These costs screen out people whose participation would otherwise be low, while at the same time they increase participation among those who do join. As a consequence, apparently unproductive sacrifices can increase the utility of group members. Efficient religions with perfectly rational members may thus embrace stigma, self-sacrifice, and bizarre behavioral standards. Strictness works.

\section{HOW STRICTNESS LEADS TO STRENGTH}

Religion is a social phenomenon, born and nurtured among groups of people. In principle, perhaps, religion can be purely private, but in practice it appears to be much more compelling and attractive when experienced in groups. ${ }^{4}$ In the austere but precise language of economics, religion is a "commodity" that people produce collectively. My religious satisfaction thus depends both on my "inputs" and on those of others.

\footnotetext{
${ }^{3}$ This pattern of success appears well beyond the confines of contemporary Protestantism. Rosabeth Kanter in her classic study of 19th-century utopian communities found that successful communes demanded much greater sacrifices of time, energy, and money than did unsuccessful ones (Kanter 1973; Hall 1988). The Mormon church has distinctive behavioral requirements and makes heavy demands on members' time and money, yet is the fastest growing religion of the modern era (Stark 1984). And one cannot ignore the continuing importance of fundamentalism worldwide (Lawrence 1989).

${ }^{4}$ Since Christianity, Islam, and Judaism place greater emphasis on collective, congregational activity than do Buddhism, Hinduism, or Shinto, my argument applies most readily to Western religions. In another article (Iannaccone, in press), I attempted to generalize the model to accommodate both collective and privately oriented religious practices.
} 
The pleasure and edification that I derive from a Sunday service does not depend solely on what I bring to the service (through my presence, attentiveness, public singing, etc.); it also depends on how many others attend, how warmly they greet me, how well they sing or recite (in English, Latin, Hebrew, Arabic, etc.), how enthusiastically they read and pray, and how deep their commitments are. The collective side of religion encompasses numerous group activities such as listening to sermons, scriptural studies, testimonial meetings, liturgies, worship, hymn singing, and sacramental acts. However, it also extends to religious belief and religious experiences-particularly the most dramatic experiences such as speaking in tongues, miraculous healings, prophetic utterances, and ecstatic trances-all of which are more sustainable and satisfying when experienced collectively.

\section{Free-Rider Problems}

Like other collective activities, religion is susceptible to "free riding," a problem first analyzed by Mancur Olson (1965) and the subsequent focus of much social-scientific research. The problem arises whenever the members of a group receive benefits in proportion to their collective, rather than individual, efforts. Because each member benefits whether or not he contributes to the common cause, each has a strong incentive to minimize his own efforts and "free ride" off those of others. If enough members yield to this temptation, the collective activity will surely fail. Free riding has wrecked many an enterprise, from small charities to global environmental initiatives.

Although most scholars have tended to overlook the problems that religions have had with free riders, Mary Douglas (1986, pp. 23-24) cites her own anthropological work to prove that "the exception of religious organization is clearly a mistake." Indeed, she argues that it is "the history of religion [that] best bears out [Olson's] theory. . . . It does not help our understanding of religion to protect it from profane scrutiny by drawing a deferential boundary around it. Religion should not be exempted at all."

Two types of free-rider problems are particularly common in religion. The first arises in mixed populations where levels of religious commitment vary from person to person. In any such group, people with low levels of religious commitment tend to free ride off those with higher levels; they tend to take more than they give. They may do so unintentionally. Nevertheless, if only because their lower commitment inclines them to participate and contribute less than others, their mere presence dilutes a group's resources, reducing the average level of participation, enthusiasm, energy, and the like. Heterogeneity can thus undermine in- 
tense fellowships and major undertakings. Lacking a way to identify and exclude free riders, highly committed people end up saddled with anemic, resource-poor congregations. The Appendix contains a formal, gametheoretic illustration of free riding in mixed groups.

A second type of free-rider problem persists even when members share a common level of commitment. ${ }^{5}$ Participation no longer varies from person to person, but the average level of participation remains suboptimal and hence inefficient.

To see why, recall that religious commodities are collectively produced. As I have noted, this implies that individual members benefit both from their own religious participation and from that of others. But it also implies the converse: when people participate, they provide benefits to others as well as to themselves. So, for example, a church member who attends regularly, sings wholeheartedly, greets others warmly, and testifies enthusiastically enhances not just his own spiritual life but also those of his fellow members. Economists refer to such side effects as "externalities." Externalities breed inefficiency because they do not enter into the self-interested decisions of strictly rational actors. Such actors maximize personal benefits net of personal costs, not social benefits net of social costs. It follows that harmful externalities like pollution abound, whereas beneficial externalities like charity, reporting crimes, and community action go begging. Powerful externalities pose serious threats to social systems and physical environments. It should come as no surprise that they also threaten religious groups. Most citizens contribute only a tiny fraction of their personal resources to charity or to community action. Is it any surprise that they behave similarly in church?

One need not look far to find an anemic congregation plagued by free-rider problems - a visit to the nearest liberal, mainline Protestant church usually will suffice. But case studies of cults and communes provide more striking examples. In such groups, which can only survive with high levels of commitment, the costs of free riding are laid bare.

Consider, for example, the Shakers' problems with transient members. These so-called "winter Shakers" would join Shaker communities in the late fall, obtain food and shelter throughout the winter, and then leave when employment opportunities had improved. Indeed, the Shakers' problems were not limited to transients. A Shaker journal written in 1870 complains of "Mary Ann Austin [who] came \& took her 7 girls after our expenses of raising them" (Bainbridge 1982, p. 361). Census data

\footnotetext{
${ }^{5}$ I am using the word commitment to denote the value that one attaches to involvement in the group. I do not assume that highly committed people are any less rational than others or that they are less inclined to free ride. They participate more only because they derive greater utility from participation.
} 
indicating $95 \%$ defection rates among members under the age of 20 corroborate these anecdotal accounts and underscore the magnitude of the problem (Bainbridge 1982).

The Divine Principles (DP or Moonie) movement studied by Lofland in the 1960s encountered similar difficulties. Lofland describes the problems posed by "exploiters" whose motives for joining DP conflicted with or undermined the goals of the movement. Some merely "attempted to extract some nonreligious benefit from the DP's, such as inexpensive room and board, money, . . . or sex" (Lofland 1977, p. 152). Others actually used DP as a base from which to recruit customers for their own, competing, spiritualist churches (p. 156).

Free riding was by no means unique to the Shakers and the DP movement. Hines (1983) claims that "social misfits," "personal dissension," and inadequate "screening" undermined most utopian colonies in California. "Commitment problems" likewise plagued most of the 19thcentury communes studied by Kanter (1973; cf. Hall 1988). Charles Guide's observation, quoted by Kanter (1973, pp. 157-58), is particularly apt: "Perhaps the gravest [peril] of all lies in the fact that these colonies are threatened as much by success as by failure. . . . If they attain prosperity they attract a crowd of members who lack the enthusiasm and faith of the earlier ones and are attracted only by self-interest." This perverse dynamic threatens all groups engaged in the production of collective goods, and it applies to enthusiasm, solidarity, and other social benefits no less than to material resources.

\section{Reducing Free Riding}

Although it is theoretically possible for religious groups to overcome their free-rider problems through screening and monitoring, such schemes prove unworkable in practice. For example, one theoretically ideal solution is for groups to "internalize" their externalities by charging substantial membership dues and then using those funds to subsidize individual participation. In other words, the group should pay people to participate fully. But this solution requires that individual behavior be accurately observed and appropriately rewarded. In reality, the aspects of religious participation that confer the greatest external benefits (effort, enthusiasm, solidarity, etc.) are intrinsically difficult to monitor and reward. ${ }^{6}$ The willingness to pay membership dues is a poor proxy for these qualities because income correlates weakly with most dimensions of religious com-

\footnotetext{
${ }^{6}$ Similar problems arise in the workplace and the home. A growing economic literature seeks to explain features characteristic of employment and marriage contracts as being means to reduce "shirking" (see Allen 1990).
} 
mitment, and any attempt to directly subsidize the observable aspects of religious participation (such as church attendance) will almost certainly backfire. The Salvation Army will readily attest that the promise of free meals guarantees an audience of less than average commitment. ${ }^{7}$ How much greater would be the temptation to feign belief in the face of cash compensation? In practice, therefore, few churches reward attendance, sell their services, charge for memberships, or compensate any but a few full-time workers. ${ }^{8}$

There remains, however, an indirect solution to the free-rider problem. Instead of subsidizing participation, churches can penalize or prohibit alternative activities that compete for members' resources. In mixed populations, such penalties and prohibitions tend to screen out the less committed members. They act like entry fees and thus discourage anyone not seriously interested in "buying" the product. Only those willing to pay the price remain. The Appendix proves this result for a gametheoretic model.

Penalties and prohibitions can also raise average levels of group participation and group utility in homogeneous populations (whether they began as homogeneous or became so after the prohibitions persuaded the less committed members to leave). To see why, note that prohibiting an activity effectively increases its price, since the activity's full cost now includes the penalties that may be meted out if it is discovered. Increasing the price of an activity reduces the demand for it, but increases the demand for its substitutes, that is, for competing activities. Hence, a religious group can indirectly increase its members' levels of participation by prohibiting or otherwise increasing the cost of alternative activities. Governments often employ similar strategies. For example, many countries encourage the use of public transportation both directly, through subsidized fares, and indirectly, through special taxes and constraints on automobile usage.

Penalties and prohibitions increase group welfare if two conditions are satisfied. The first is that the inefficiency induced by free riding must be relatively large; otherwise costly efforts to reduce it are not worth the trouble. The second is that the activity being taxed, penalized, or prohibited must be a close substitute for the desired alternative; otherwise increasing the cost of the former will not significantly increase the demand

\footnotetext{
${ }^{7}$ The Salvation Army is, of course, well aware of this phenomenon and uses it to further its goal of reaching indigents who are not normally found in churches. But note that even the army makes a point of scheduling its sermons before the free meals.

${ }^{8}$ Exceptions exist. For example, many Jewish synagogues collect membership dues, and many Protestant churches used to charge pew-rental fees.
} 
for the latter. For the mathematical derivation of these results, see Iannaccone $(1992 b)$.

It might at first seem that any group unable to monitor members' participation in its own activities will have an even harder time restricting their involvement in other activities, but this is not so. It is often much easier to observe and penalize mere involvement in competing groups than it is to accurately determine the level of involvement in one's own group. Alternatively, it may be possible to demand of members some distinctive, stigmatizing behavior that inhibits participation or reduces productivity in alternative contexts-having shaved heads, wearing pink robes, or being in an isolated location does the job quite effectively. Commenting on his religion's distinctive dress and grooming requirements, a Sikh put it thus: "The Guru wanted to raise a body of men who would not be able to deny their faith when questioned, but whose external appearance would invite persecution and breed the courage to resist it" (Singh 1953, p. 31). ${ }^{9}$

Restrictions on smoking, drinking, eating, sex, and other potentially private activities are harder to enforce, and it is possible that guilt, habit, and other self-enforcement mechanisms help keep members in line. Even in the absence of internal constraints, however, deception remains costly. A secret sexual liaison is not at all the same as an open relationship, private drinking from a hidden bottle is a poor substitute for social drinking at bars and parties, and a concealed smoking habit may be more trouble than it is worth. Restrictive religions can, and often do, raise the cost of deception by limiting the size of congregations, holding meetings in members' homes, and demanding that members routinely socialize with each other.

Costly strictures thus mitigate the externality problems faced by religious groups. Distinctive diet, dress, grooming, and social customs constrain and often stigmatize members, making participation in alternative activities more costly. Potential members are forced to choose whether to participate fully or not at all. The seductive middle ground is eliminated, and, paradoxically, those who remain find that their welfare has been increased. It follows that perfectly rational people can be drawn to decidedly unconventional groups. This conclusion sharply contrasts with the view, popular among psychiatrists, clinical psychologists, and the media, that conversion to deviant religious sects and cults is inherently

\footnotetext{
${ }^{9}$ As this quotation indicates, religious groups may consciously manipulate their doctrines and practices in order to limit free riding. The model does not, therefore, depend solely on evolutionary forces to weed out ineffective practices. Although such forces are surely at work, given the hundreds of new religions that are born and die every century, their effect is greatly reinforced by deliberate adaptations aimed at increasing commitment (Kanter 1973; Hechter 1987; Kraybill 1989a).
} 
pathological, the consequence of either psychological abnormality or coercive "brainwashing" (Robbins 1988', pp. 72-89). ${ }^{10}$

\section{EVIDENCE AND APPLICATIONS}

The proposed model does not merely "rationalize" strange behaviors and deviant demands. It also predicts the empirical correlates of strictness, extends Kelley's thesis, and throws new light on the hoary theme of church versus sect.

\section{Measuring Strictness}

To address these issues, one must first assess the relative "strictness" of different religions. Objective measures are hard to obtain, both because religious demands take many forms and because most data sources ignore the issue of cost, ${ }^{11}$ but comparisons based on expert judgment and common sense will suffice here.

Consider, for example, the three major Jewish denominations. It goes without saying that Orthodox Judaism imposes the greatest costs on its members and that Reform Judaism imposes the least. Conservative Judaism falls between these extremes, though it is generally closer to Reform than to Orthodox. One may verify this ranking any number of ways-by employing expert judgment, conventional wisdom, official doctrine, or observable practices - the results never change.

Although Protestant denominations prove harder to classify, some generalizations again lie beyond dispute. Scholars, citizens, journalists, and church members all agree that "sectarian" groups, like the Jehovah's Witnesses, Mormons, and Seventh Day Adventists, are stricter and more demanding than mainline denominations like the Episcopalians, Methodists, and the United Church of Christ. Indeed, the standard ranking begins with the "liberal," "mainline" denominations, and runs through "evangelicals," "fundamentalists," "pentecostals," and finally "sects." A large body of empirical research confirms the general validity of this ranking (Stark and Glock 1968; Roof and McKinney 1987, pp. 72-147). The members of more conservative denominations do indeed adopt a

\footnotetext{
${ }^{10}$ The conclusion also contradicts the view of "commitment mechanisms" based on cognitive dissonance theory (e.g., Kanter 1973, p. 76). In contrast to rational choice, cognitive dissonance ultimately involves a lapse in rationality or, at the very least, an experience-induced attitude change.

${ }^{11}$ Surveys with dozens or even hundreds of religious items routinely ignore the costs that congregations or denominations impose on their members. (See, e.g., the General Social Survey, Gallup polls, or the Search Institute's recent 374-item "Effective Christian Education" survey of Protestant congregations.)
} 
more restrictive lifestyle than their mainline counterparts. They are, for example, less likely to drink (Cochran, Beeghley, and Bock 1987), engage in premarital sex (Beck, Cole, and Hammond 1991), or experiment with alternative, "new age" religions (Tamney et al. 1991; Donahue 1991).

Expert judgments refine the standard Protestant ranking. Consider, for example, a study that surveyed 21 experts (church historians, sociologists of religion, denominational leaders, and seminary educators) nominated as "maximally knowledgeable and representative of the total spectrum of denominations" (Hoge and Roozen 1979, E-4). ${ }^{12}$ The experts rated 16 major Protestant denominations on a series of seven-point scales. One of these scales provides an excellent operational definition of strictness and cost. It asks the respondent to rate each denomination according to the following criteria: "Does the denomination emphasize maintaining a separate and distinctive life style or morality in personal and family life, in such areas as dress, diet, drinking, entertainment, uses of time, marriage, sex, child rearing, and the like? Or does it affirm the current American mainline life style in these respects?"13 The results are reassuring. Liberal mainline denominations (Episcopal, Methodist, Presbyterian, and the United Church of Christ) scored as the least distinctive, followed by moderate mainline denominations (Evangelical Lutheran, Reformed Church, Disciples of Christ, and American Baptist), conservatives and evangelicals (Missouri Synod Lutheran and Southern Baptist), and, finally, fundamentalists, pentecostals, and sects (Nazarene, Assemblies of God, Seventh Day Adventist, and Mormon). ${ }^{14}$

In order to assess this scale's reliability and to expand the set of denom-

${ }^{12}$ Hoge surveyed expert opinion in an effort to identify the empirical determinants of church growth. In the current context, his data provide something approaching a "double blind" experiment, since neither he nor his subjects anticipated using the results to predict church attendance, contributions, or other individual-level behaviors.

${ }^{13}$ One reviewer expressed concern that this item and my use of it fail to distinguish between "true costly stigma" and "mere distinctiveness." However, I model this difference as a matter of degree. Social or geographical isolation varies along a continuum (from wilderness communes to Amish communities to Orthodox Jewish enclaves to Catholic neighborhoods), as do restrictions on grooming, dietary habits, sexual behavior, family life, drug use, etc. The theory concerns any "opportunity" cost, with no sharp line between large and small or real and symbolic. Note also that, when asked to score denominations according to the strictness of their beliefs, the experts produced a ranking that correlates almost perfectly with the distinctiveness ranking $(r=.91)$.

${ }^{14}$ One might wonder whether the experts' judgments simply mirrored the conventional denominational ranking. But the experts ordered the denominations quite differently when asked about their strength of ethnic identity and their style of governance (Hoge 1979). 
Strict Churches

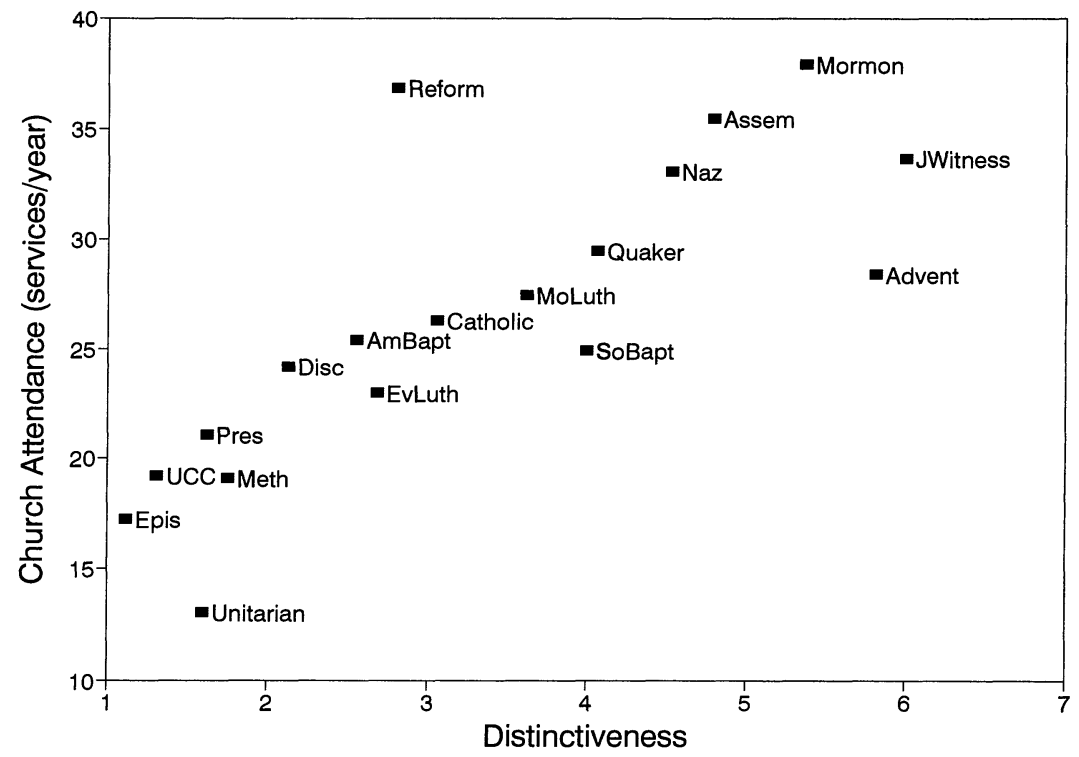

FIG. 1.-Attendance versus distinctiveness

inations, I replicated the survey using 16 new experts. ${ }^{15}$ Two findings stand out. First, the rankings remain unchanged across the two studies. Despite the passage of 15 years and the use of different raters, the correlation between the new and old distinctiveness scales is an astonishing .99. Second, the level of agreement among the experts is extraordinarily high. The reliability of denominational scores (as measured by Cronbach's alpha) is over $.98,{ }^{16}$ and the mean correlation between each expert's

${ }^{15}$ My sample of experts included sociologists of religion, religious historians, and other religious scholars. I chose them less systematically than did Hoge, anticipating a second, more sophisticated replication. But the initial results mirrored Hoge's so closely that further work seemed pointless. I also had the experts rate the three Jewish denominations. As expected, they unanimously scored Reform Judaism the least distinctive and Orthodox Judaism the most distinctive. Details are available on request.

${ }^{16}$ Typical survey-based scales are formed by summing an individual respondent's (standardized) scores on several survey items. Cronbach's alpha then provides a measure of interitem correlation across the sample of respondents. The present scale is formed by summing the (standardized) responses of 16 different experts. Hence, each individual expert acts like a different "item" or measure of the underlying characteristic (distinctiveness), and each denomination acts as a separate case. In this context, Cronbach's alpha provides an index of correlation among the experts, and thus is a measure of interrater reliability. The presumed statistical model is $s_{\imath \jmath}=t_{j}+e_{i j}$, where $s_{\imath}$ denotes the $i$ th expert's distinctiveness score for the $j$ th denomination, $t_{j}$ denotes the $j$ th denomination's true distinctiveness level, and $e_{i j}$ denotes the (random) error in the $i$ th expert's judgment regarding the $j$ th denomination. 
ratings and the average standardized ratings of all other experts is .85 . The experts' average score for each denomination can be read off the horizontal axis of figure 1 .

\section{A Theory of Church and Sect}

I have shown that cost-based scales are reliable. They are also useful, yielding a formal theory of church and sect more elegant, general, and empirically fruitful than its predecessors.

Traditional theories of church and sect have been justly criticized as not being theories at all, but rather complex, multiattribute typologies that offer static descriptions at the expense of testable implications (Stark and Bainbridge 1985, pp. 19-23). ${ }^{17}$ The ideal-typical sect might be defined as a religious organization with a highly committed, voluntary, and converted membership, a separatist orientation, an exclusive social structure, a spirit of regeneration, and an attitude of ethical austerity and demanding asceticism. The ideal-typical church would have its own complex list of attributes: birth-based membership, inclusiveness and universalism, hierarchical structures, an adaptive, compromising stance vis-à-vis the larger society, and so forth. Not withstanding a certain "intuitive rightness," such lists fail to accommodate the majority of realworld religions, provide limited insight into nonideal, "mixed-type" cases, and lack predictions or causal arguments linking one attribute to another.

In contrast, the present scheme is simple, unidimensional, and powerfully predictive. It derives from a model that characterizes numerous religious demands as functionally equivalent solutions to free-rider problems. Religions that demand similar levels of sacrifice should therefore display fundamental behavioral similarities, despite the peculiarities of their individual histories, theologies, and organizational structures. ${ }^{18}$

Similarities do in fact appear when we group religions according to the (rated) stringency of their demands. Consider, for example, the summary statistics in table 1 obtained from the General Social Survey, 1984-90. (The table's membership groupings reflect the respondents' self-described religious preferences.) Compared to members of other Protestant denomi-

\footnotetext{
${ }^{17}$ Weber introduced the church-sect distinction to sociology ([1904-5] 1958, [1922] 1963). Adam Smith introduced virtually the same distinction to economics more than a century earlier. Smith contrasted "established churches" and "small sects" at length in The Wealth of Nations ([1776] 1965, pp. 740-66).

${ }^{18}$ For the purposes of the analysis it does not matter whether these demands take the form of explicit consumption restrictions, such as dietary laws, or behaviors that isolate or stigmatize members so as to restrict their interactions with nonmembers.
} 
TABLE 1

Protestant Denominational Differences

\begin{tabular}{|c|c|c|c|c|c|}
\hline & Liberal & Moderate & Conservative & Sects & $t$-value* \\
\hline $\begin{array}{l}\text { Household income (in thousands } \\
\text { of dollars per year) } \ldots \ldots \ldots \ldots \ldots \ldots . . . . .\end{array}$ & $\begin{array}{c}38.0 \\
(23.2)\end{array}$ & $\begin{array}{c}31.0 \\
(20.9)\end{array}$ & $\begin{array}{c}31.6 \\
(20.7)\end{array}$ & $\begin{array}{c}27.0 \\
(20.0)\end{array}$ & 8.9 \\
\hline Respondent education (in years) .. & $\begin{array}{c}13.8 \\
(2.92)\end{array}$ & $\begin{array}{c}12.5 \\
(2.86)\end{array}$ & $\begin{array}{c}12.1 \\
(2.84)\end{array}$ & $\begin{array}{c}11.3 \\
(3.02)\end{array}$ & 15.1 \\
\hline $\begin{array}{l}\text { Sunday attendance (services at- } \\
\text { tended per year) }\end{array}$ & $\begin{array}{c}20.9 \\
(25.4)\end{array}$ & $\begin{array}{c}25.2 \\
(29.2)\end{array}$ & $\begin{array}{c}31.3 \\
(33.4)\end{array}$ & $\begin{array}{c}48.5 \\
(42.7)\end{array}$ & 13.7 \\
\hline $\begin{array}{r}\text { Weekday attendance (\% attending } \\
\text { weekday meetings) }\end{array}$ & $\begin{array}{c}2.7 \\
(16.4)\end{array}$ & $\begin{array}{c}6.3 \\
(24.3)\end{array}$ & $\begin{array}{c}11.5 \\
(31.8)\end{array}$ & $\begin{array}{c}32.3 \\
(46.8)\end{array}$ & 14.4 \\
\hline $\begin{array}{l}\text { Church contributions (dollars per } \\
\text { year) }\end{array}$ & $\begin{array}{c}584 \\
(1,388)\end{array}$ & $\begin{array}{l}473 \\
(937)\end{array}$ & $\begin{array}{c}905 \\
(1,843)\end{array}$ & $\begin{array}{c}862 \\
(1,818)\end{array}$ & 1.8 \\
\hline $\begin{array}{l}\text { Church contributions ( } \% \text { of yearly } \\
\text { income) }\end{array}$ & $\begin{array}{c}1.94 \\
(6.49)\end{array}$ & $\begin{array}{c}1.94 \\
(3.80)\end{array}$ & $\begin{array}{c}2.81 \\
(4.65)\end{array}$ & $\begin{array}{c}3.16 \\
(4.81)\end{array}$ & 2.3 \\
\hline $\begin{array}{l}\text { Membership in church-affiliated } \\
\text { groups ( } \% \text { belonging) } \ldots \ldots \ldots \ldots \ldots . . .\end{array}$ & $\begin{array}{c}37.8 \\
(48.5)\end{array}$ & $\begin{array}{c}40.1 \\
(49.0)\end{array}$ & $\begin{array}{c}44.6 \\
(49.7)\end{array}$ & $\begin{array}{c}49.5 \\
(50.1)\end{array}$ & 3.6 \\
\hline $\begin{array}{l}\text { Secular memberships (no. of mem- } \\
\text { berships) } \ldots \ldots \ldots \ldots \ldots \ldots \ldots \ldots \ldots \ldots \ldots \ldots \ldots \ldots\end{array}$ & $\begin{array}{c}1.90 \\
(1.91)\end{array}$ & $\begin{array}{c}1.48 \\
(1.74)\end{array}$ & $\begin{array}{c}1.27 \\
(1.52)\end{array}$ & $\begin{array}{c}.91 \\
(1.30)\end{array}$ & 9.4 \\
\hline $\begin{array}{l}\text { Strength of affiliation (\% claiming } \\
\text { to be "strong" members) }\end{array}$ & $\begin{array}{c}32.6 \\
(46.9)\end{array}$ & $\begin{array}{c}38.7 \\
(48.7)\end{array}$ & $\begin{array}{c}45.5 \\
(49.8)\end{array}$ & $\begin{array}{c}56.0 \\
(49.7)\end{array}$ & 8.5 \\
\hline Biblical literalism ( $\%$ believing) .. & $\begin{array}{c}23.2 \\
(42.3)\end{array}$ & $\begin{array}{c}40.4 \\
(49.1)\end{array}$ & $\begin{array}{c}57.8 \\
(49.4)\end{array}$ & $\begin{array}{c}68.1 \\
(46.6)\end{array}$ & 15.7 \\
\hline Belief in afterlife ( $\%$ believing) $\ldots$ & $\begin{array}{c}79.5 \\
(40.4)\end{array}$ & $\begin{array}{c}85.1 \\
(35.6)\end{array}$ & $\begin{array}{c}88.9 \\
(31.4)\end{array}$ & $\begin{array}{c}87.8 \\
(32.6)\end{array}$ & 3.5 \\
\hline 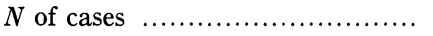 & 763 & 1,802 & 941 & 575 & \\
\hline
\end{tabular}

SouRCE. - NORC General Social Survey, 1984-90; sample consists of nonblack, non-Catholic Christians.

NotE. - In first four cols., nos. shown are means; nos. in parentheses are SDs. Definitions of denominational groups: liberal $=$ Christian (Disciples of Christ), Episcopalian, Methodist, and United Church of Christ; moderate = American Baptist, Evangelical Lutheran, Presbyterian, and Reformed churches; conservative = Missouri Synod Lutheran and Southern Baptist; and sects = Assemblies of God, Church of Christ, Church of God, Jehovah's Witness, Nazarene, Seventh Day Adventist, and other fundamentalists and pentecostals.

* $t$-values are for two-tailed test comparing means for liberal and sect members. 
American Journal of Sociology

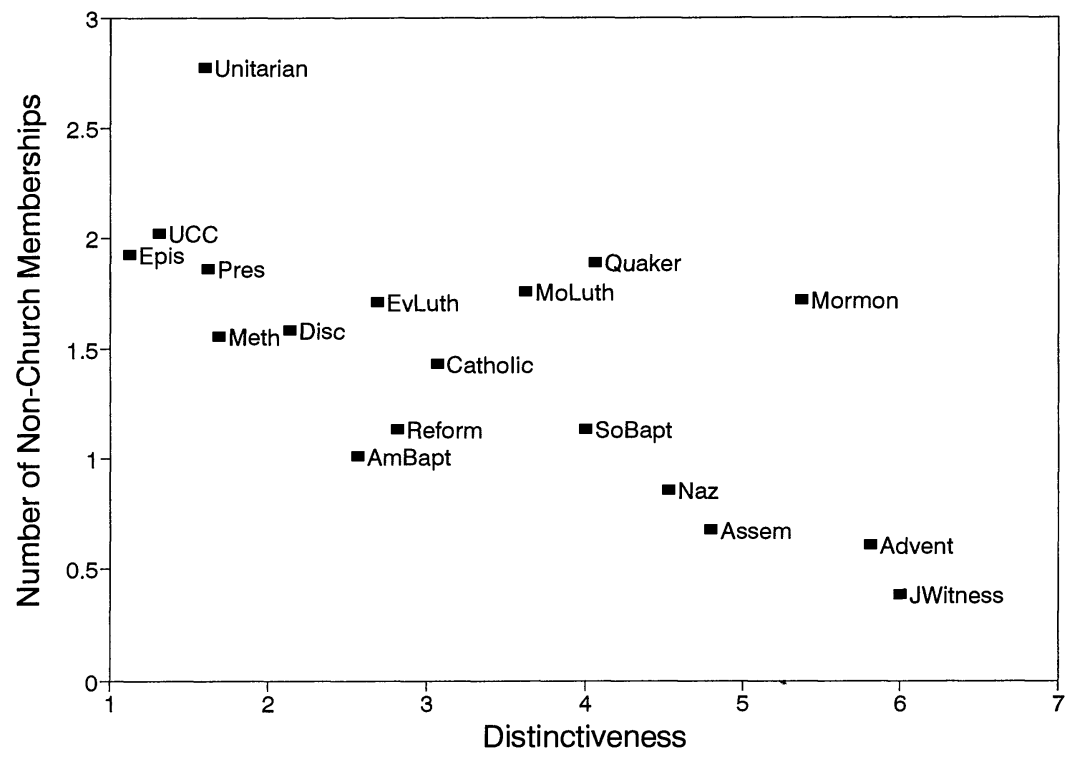

FIG. 2.-Nonchurch memberships

nations, sect members are poorer and less educated, contribute more money and attend more services, hold stronger beliefs, belong to more church-related groups, and are less involved in secular organizations. The differences are strong, striking, and statistically significant. Moreover, for virtually every variable the pattern of variation is monotonic, increasing (or decreasing) steadily as one moves from liberal to moderate to conservative and, finally, to sect groups. ${ }^{19}$ Figures $1-4$ show that these relationships remain strong even when disaggregated to the level of individual denominations. In figure 1, for example, the correlation between denominational distinctiveness and average rates of church attendance is .82 .

The cost-based theory of church and sect rebuts the complaint that religious typologies are inherently ad hoc, rooted in the particulars of Christian theology and European church history and inapplicable to other religious traditions (Roberts 1984, p. 225; Eister 1967). The theory

\footnotetext{
${ }^{19}$ The patterns in table 1 are not unknown to the sociology of religion, although figs. 1-4 do provide a new view of the data. Numerous surveys of Protestant Christian groups find that denominations tend to fall into distinct types (Stark and Glock 1968; Roof and McKinney 1987). The present analysis builds on the work of Johnson (1963, pp. 542, 544; see Johnson 1971) who defined "churches" as religious organizations that "accept the social environment," embracing the norms and values of the prevailing culture, and contrasted them to "sects" that "reject the social environment."
} 


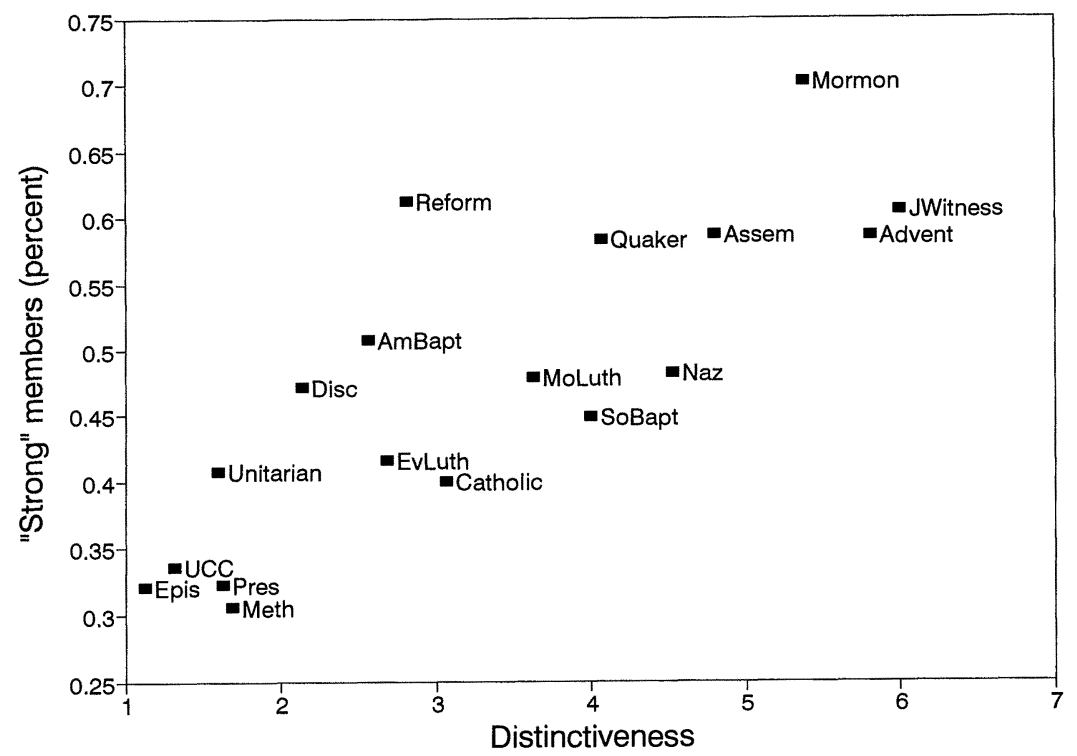

FIG. 3.-Strength of affiliation

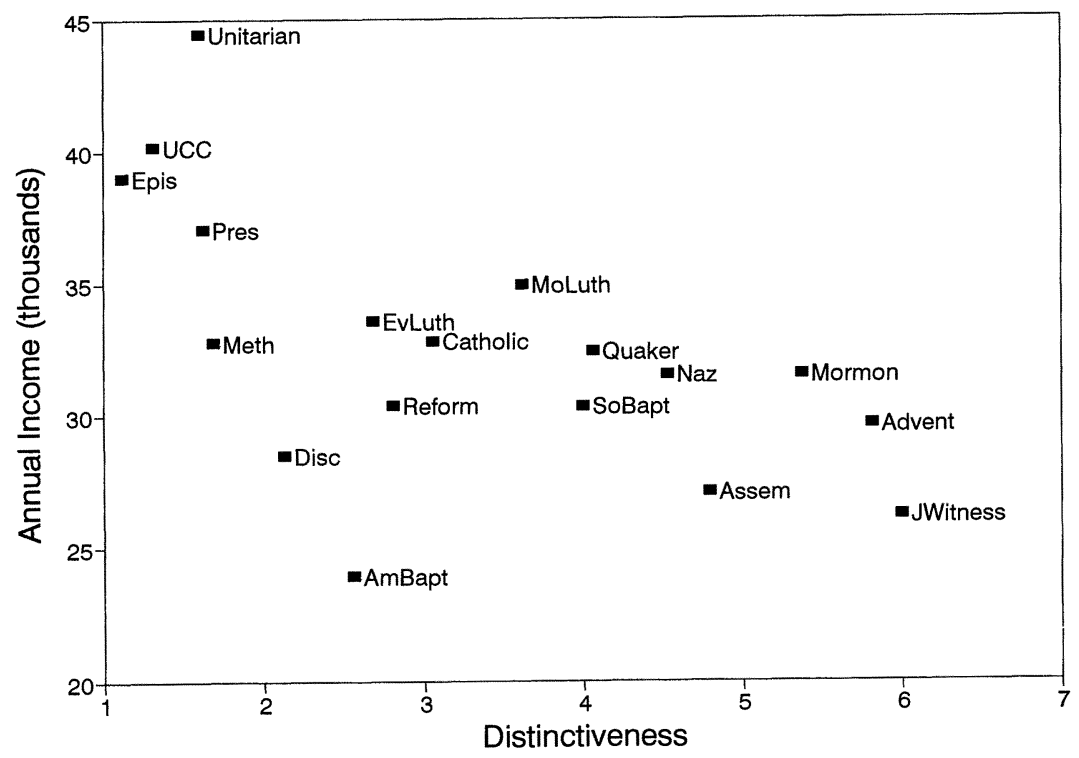

FIG. 4.-Income versus distinctiveness 
TABLE 2

JeWish Denominational Differences

\begin{tabular}{|c|c|c|c|}
\hline & Reform & Conservative & Orthodox \\
\hline \multicolumn{4}{|l|}{ Individual practices: } \\
\hline Attends synagogue regularly $(\%) \quad \ldots \ldots \ldots \ldots \ldots$ & 8.6 & 19.0 & 54.1 \\
\hline Lights candles each Friday $(\%) \ldots \ldots \ldots \ldots \ldots \ldots$ & 5.4 & 15.3 & 56.8 \\
\hline Avoids money on Sabbath $(\%) \quad \ldots \ldots \ldots \ldots \ldots \ldots$ & 6.5 & 13.1 & 57.7 \\
\hline \multicolumn{4}{|l|}{ Household practices: } \\
\hline Buys kosher meat $(\%) \quad \ldots \ldots \ldots \ldots \ldots \ldots \ldots \ldots \ldots \ldots \ldots \ldots \ldots \ldots \ldots \ldots$ & 3.5 & 20.7 & 68.5 \\
\hline Separates meat and dairy dishes $(\%) \ldots \ldots \ldots \ldots \ldots$ & 3.4 & 18.9 & 66.7 \\
\hline Lights Hanukkah candles $(\%) \quad \ldots \ldots \ldots \ldots \ldots \ldots \ldots$ & 53.4 & 66.9 & 76.6 \\
\hline 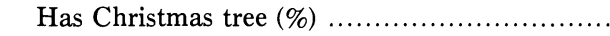 & 21.8 & 15.4 & 7.2 \\
\hline \multicolumn{4}{|l|}{ Networks: } \\
\hline Closest friends are all Jews (\%) ... & 7.6 & 15.8 & 39.1 \\
\hline Lives in Jewish neighborhood (\%) & 6.6 & 11.5 & 36.0 \\
\hline Opposes marrying non-Jew (\%) $\ldots$ & 1.9 & 9.6 & 47.7 \\
\hline \multicolumn{4}{|l|}{ Household contributions per year: } \\
\hline Gives more than $\$ 1,000$ to Jewish causes (\%) & 5.4 & 9.44 & 22.5 \\
\hline $\begin{array}{l}\text { Gives more than } \$ 1,000 \text { to nonJewish } \\
\text { causes }(\%) \ldots \ldots \ldots \ldots \ldots \ldots \ldots \ldots \ldots \ldots \ldots \ldots \ldots \ldots \ldots \ldots \ldots \ldots\end{array}$ & 6.53 & 4.31 & .0 \\
\hline \multicolumn{4}{|l|}{ Volunteer hours per week: } \\
\hline Hours worked for Jewish organizations & $\begin{array}{c}1.08 \\
(4.45)\end{array}$ & $\begin{array}{c}2.34 \\
(7.40)\end{array}$ & $\begin{array}{c}5.62 \\
(14.54)\end{array}$ \\
\hline Hours worked for secular organizations ........... & $\begin{array}{c}4.02 \\
(8.98)\end{array}$ & $\begin{array}{c}3.62 \\
(8.81)\end{array}$ & $\begin{array}{c}2.24 \\
(9.34)\end{array}$ \\
\hline \multicolumn{4}{|l|}{ Organizational memberships: } \\
\hline Jewish (outside of synagogue) ... & $\begin{array}{c}.55 \\
(1.45)\end{array}$ & $\begin{array}{c}.85 \\
(1.49)\end{array}$ & $\begin{array}{c}1.46 \\
(3.24)\end{array}$ \\
\hline Non-Jewish & $\begin{array}{c}1.67 \\
(3.09)\end{array}$ & $\begin{array}{c}1.45 \\
(2.35)\end{array}$ & $\begin{array}{c}.721 \\
(1.36)\end{array}$ \\
\hline 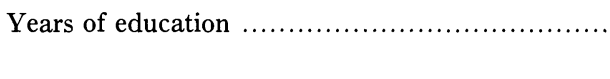 & $\begin{array}{l}15.8 \\
(2.54)\end{array}$ & $\begin{array}{c}15.2 \\
(3.30)\end{array}$ & $\begin{array}{c}14.8 \\
(3.62)\end{array}$ \\
\hline Household income (in thousands of dollars) ........ & $\begin{array}{c}64.7 \\
(46.7)\end{array}$ & $\begin{array}{c}55.5 \\
(42.8)\end{array}$ & $\begin{array}{c}41.7 \\
(35.7)\end{array}$ \\
\hline$N$ of cases $\ldots \ldots \ldots \ldots$ & 797 & 720 & 111 \\
\hline
\end{tabular}

SouRCE. - 1990 National Jewish Population Survey.

Note.-Nos. in parentheses are SDs; for each variable, the two-tailed $t$-test comparing means for Reform and Orthodox is significant at the $5 \%$ level.

grows from abstract considerations of collective production, rationality, and free riding and should therefore apply to other, collectively oriented religions, such as Judaism and Islam.

This proves, in fact, to be the case. Data from the 1990 National Jewish Population Survey reveal patterns of interdenominational variation virtually identical to those observed within Protestantism. (See table 2, which arranges Jewish denominations using the same distinctiveness 
scale used in table 1.) Compared to the members of Reform Judaism, Orthodox Jews are poorer and somewhat less educated, devote more time and money to religious activities, hold stronger religious beliefs, are more involved in their own religious community, and separate themselves more thoroughly from non-Jewish society. Here again, the differences are strong, significant, and consistent. One might even say that Jewish denominations fit the idealized church-sect continuum even more neatly than do the Christian denominations. ${ }^{20}$

\section{Putting the Theory to Work}

Unlike traditional typologies, the proposed theory of church and sect tells a causal story. It claims that a high-cost group maintains its strict norms of conduct precisely because they limit participation in competing activities and thereby raise levels of participation within the group. ${ }^{21}$ The theory thus predicts that increased strictness (or distinctiveness, or costliness) leads to higher levels of church attendance and church contributions, closer ties to the group, and reduced involvement in competing groups.

The observed patterns in tables 1 and 2 support this prediction. Relative to their more mainstream counterparts, members of sectarian groups-both Christian and Jewish-attend more religious services, contribute more money, and (in the Jewish case, at least) choose more of their closest friends from within their religion. They are also less involved in competing activities. They hold fewer memberships in outside groups, contribute less to outside causes, and have fewer outside friends. This last set of findings deserves special emphasis because it reverses a well-known individual-level pattern. Calculated at the level of the individual, correlations between church participation and outside participation are consistently positive and significant. People who regularly participate in church activities also tend to involve themselves in a wide range of organizations and activities outside of the church. So, for example, the zero-order, individual-level correlations between dollars contributed to Jewish causes and dollars contributed to non-Jewish causes are positive for all types of Jews (correlations are .56 for Reform, .57 for Conservative, and .12 for

\footnotetext{
${ }^{20}$ The results in table 2 come from the first truly random sample of American Jewry, the 1990 Jewish National Population Survey, gleaned from an initial survey of more than 100,000 Americans (Goldstein and Kosmin 1991). For similar results based on a 1970 survey of American Jews, see Lazerwitz and Harrison (1979).

${ }^{21}$ Traditional church-sect theory does not generate this sort of a prediction. At best, it provides a definition of the sect as a "type" of religion that separates itself from society and maintains high levels of participation and draws its membership from society's poor (see Roberts 1990, pp. 182-93).
} 
Orthodox). The corresponding correlations between numbers of Jewish and non-Jewish organizational memberships are positive as well $(.19, .33$, and .32 , for the three respective groups). For Christians the correlation between membership in church-affiliated groups and the number of nonreligious memberships is .26. But when they are calculated at the level of denominational averages, all these correlations are negative. Hence both theory and data underscore that the group-level patterns represent more than the mere aggregation of individual-level correlations.

Graphs provide another way to confirm the theory's predictions. Figures 1-3 show that the categorical patterns of table 1 in no way depend on a few outlying denominations. Figure 1 plots the relationship between (expert-rated) distinctiveness and average attendance in all available denominations, including Catholic. Figure 2 confirms the prediction that distinctiveness functions to limit members' involvement in alternative activities and competing sources of satisfaction. Sect members do indeed forgo secular memberships. Figure 3 provides persuasive evidence that the members of costly groups free ride less. Even though mainline denominations demand relatively little of their members, far fewer of those members describe themselves as "strong" members of their religion.

The regressions in table 3 show that the group's impact persists even after controlling for demographic and socioeconomic characteristics, such as age, income, sex, education, race, and marital status. Columns 1 and 5 regress attendance and contribution rates on background and SES variables alone. Columns 2 and 6 add a measure of denominational strictness or cost, the distinctiveness scores generated by the experts. In both regressions, the explanatory power of denominational distinctiveness is truly astonishing, particularly when one recalls that all the other variables are measured at the individual level. Distinctiveness works in the predicted direction, is highly significant, more than doubles $R^{2}$ in the attendance regression, and increases $R^{2}$ by half in the contribution equations. Columns 3 and 7 show that the signs, significance, and relative magnitudes of the estimated equation remain essentially unchanged under a nonlinear tobit specification (which combines features of both probit and OLS regression in order to account for censoring in the dependent variables). ${ }^{22}$ Columns 4 and 8 add several more individual-level variables to test whether the distinctiveness effect works through its correlation with (or impact on) individual beliefs and choice of spouse. But

\footnotetext{
${ }^{22}$ Annual rates of church attendance are censored at both ends, since they cannot exceed 52 ("weekly") nor fall below zero ("never"). Contribution rates are censored only from below. Tobit regression maximizes a likelihood function in which endpoint observations enter in a manner analogous to probit regression and internal observations enter in a manner analogous to standard OLS regression (cf. Greene 1990, p. 727).
} 


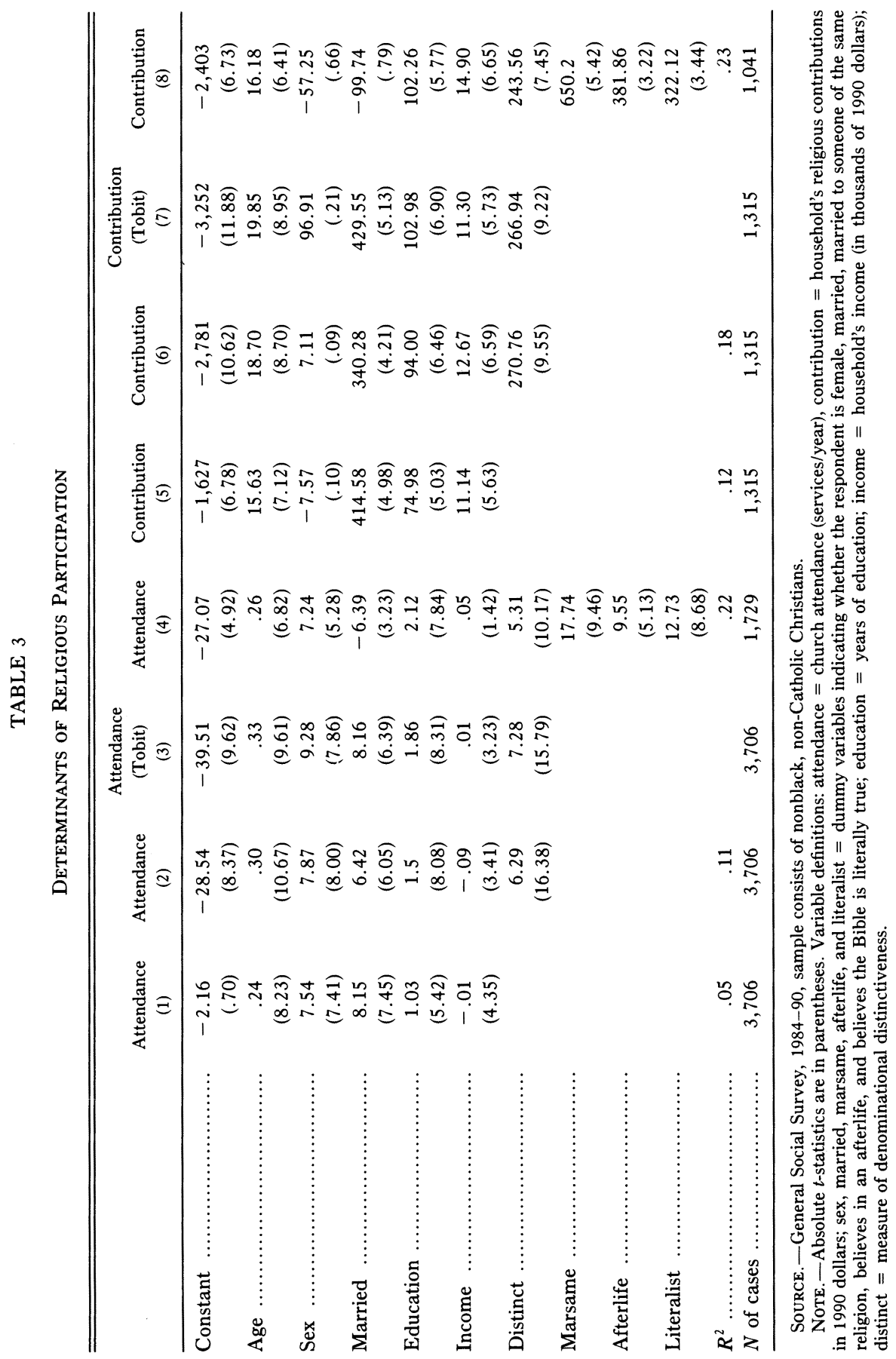


even though these variables prove statistically significant, they in no way wash out the direct impact of denominational distinctiveness. Indeed, I could not alter this fundamental result with any reasonable alternative subsample, estimation technique, time frame, or method of assessing denominational characteristics, ${ }^{23}$ nor have I found contradictory results in regressions for other key dependent variables such as memberships and contributions outside of the church, church friends, and strength of membership. The corresponding Jewish survey regressions, available on request, yield essentially the same results.

We thus arrive at a persistent and powerfully sociological finding. The character of the group -its distinctiveness, costliness, or strictness-does more to explain individual rates of religious participation than does any standard, individual-level characteristic, such as age, sex, race, region, income, education, or marital status. The impact appears across both Christian and Jewish denominations, and it remains strong even after controlling for personal beliefs. ${ }^{24}$

\section{The Social Correlates of Sectarianism}

A final set of predictions concerns the type of people most likely to affiliate with a group that limits one's involvement in alternative activities or constrains one's consumption of secular commodities. Simply put, those most likely to join are those with the least to lose. Losses grow in proportion to both the quantity and the quality of one's ties to the outside world. You are therefore less likely to join (or remain active in) an exclusive sect if you have an extensive set of social ties to friends and family outside the sect. You are more likely to join if you lack many such ties and are still more likely to join if you have friends or family in the sect. Stated in terms of cost and benefit, these predictions seem embarrassingly obvi-

${ }^{23}$ The key result remains robust despite $(a)$ changed samples (e.g., Protestants only, whites only, married respondents, or the exclusion of extreme sects), $(b)$ different estimation techniques (OLS, tobit, or logit), $(c)$ alternate time frames (1984-90, 1972-83, or 1972-90), (d) alternative denominational measures (1990 distinctiveness ranking, 1979 ranking, and denominational dummies that distinguish "liberal Protestants," "moderate Protestants," "conservative Protestants," "sect" members, and Catholics), and ( $e$ ) the inclusion of additional explanatory variables (political orientation and a variety of attitudinal measures).

${ }^{24}$ Some researchers have claimed that Kelley's observations concerning the "institutional" determinants of participation, commitment, and membership were biased by a neglect of "contextual" factors, such as the average age, income, education, and birthrate within the membership of various denominations (Hoge 1979, pp. 193-95). Insofar as Kelley's thesis concerns commitment and participation, the present data support Kelley over his critics. For evidence that the criticism may not even apply to membership growth, see Kelley (1979, pp. 334-43). 
ous. Yet it took years of research before scholars would accept that a potential member's social ties predict conversion far more accurately than his or her psychological profile.

Economic ties work in much the same manner as social ties. There is little chance that a successful business executive will forsake all for a strict sect, let alone a wilderness commune. The opportunity costs are simply too great. But the costs are substantially less, and hence the odds of joining substantially higher, for people with limited secular opportunities, such as those with low wage rates, limited education, or minimal job experience. This prediction is consistent with the patterns observed in figure 4 and tables 1 and 2-sect members average the lowest income and education; members of the most churchlike denominations average the highest.

The prediction that sects tend to attract individuals with limited secular opportunities has two corollaries. First, classes of people experiencing relatively limited secular opportunities (such as minorities, women, and the young) are more likely than others to choose sect membership over mainline church membership. Second, a general decline in secular opportunities, such as that which occurs during recessions, will make sectarian groups more attractive relative to nonsectarian groups. Both corollaries are strongly supported by previous studies (reviewed in Iannaccone 1988), and logistic regressions, available on request, show that being young, black, female, undereducated, or poor all significantly increase the odds of being a sect member.

\section{Limits to Strictness}

Kelley's argument would seem to imply that a church always benefits from increased strictness, no matter how strict it is already. The Presbyterians would grow faster if they become more like the Southern Baptists, who would, in turn, grow faster if they became more like the Mormons. In fact, Kelley himself has stated that "strong organizations are strict . . . the stricter the stronger" (Kelley 1986, p. 95) ${ }^{25}$ In contrast, the present model implies that organizational strictness displays diminishing returns and that the optimal amount of strictness will depend on the socioeconomic characteristics of the members.

To see this, recall that in the rational choice model, increased strictness

\footnotetext{
${ }^{25}$ Kelley (1986, pp. 95-96) did follow this assertion with the parenthetical proviso that "there may be a point of diminishing returns beyond which increasing strictness does not produce significantly greater strength, and might in fact prove counterproductive." But his theoretical argument and real-world examples admit no such exceptions.
} 
adds to the attractiveness of a church only because its benefits outweigh its costs. The benefits take the form of greater group participation, commitment, or solidarity. These benefits can be quite large, since free riding is a serious problem. But they are not infinite. They must be set against the costs of strictness, costs that take the form of stigma, self-sacrifice, social isolation, and limited opportunities to earn "secular" rewards or to enjoy "worldly" pleasures. As a group becomes progressively more strict, it eventually reaches a point beyond which the additional benefits of increased strictness are outweighed by additional costs.

Consider, for example, a group that has already isolated itself geographically, thereby eliminating all part-time members (at the cost of secular social ties and occupations). It is not at all clear that people who join such a group would also wish to submit to ritual disfigurement, vows of silence, regular fasting, or the rejection of all modern conveniences. Rather, it is clear that beyond some point increased strictness/ costliness must drive away virtually all current and potential members. Even though hundreds were willing to join the Bhagwan Rajneesh in Antelope, Oregon, few would have followed him to the Arctic Circle. For any target population of potential members, there will therefore exist an optimal level of strictness. Groups that exceed this level will tend to scare off many potential members with what are perceived as excessive demands. Groups that fall short of this level of strictness will suffer from free-rider problems and hence from a pervasive lack of commitment that leaves many potential members feeling that the group has little to offer.

Kelley's thesis and data thus address only one tail of a two-tailed phenomenon. Closer inspection should reveal the existence of another class of unsuccessful groups, those that are so strict and sectarian that they simply wither and die. Stark and Bainbridge's (1985) study of more than 400 American-born sects strongly confirms this prediction. Mormons, Jehovah's Witnesses, and Seventh Day Adventists notwithstanding, only $6 \%$ of all identifiable American sects are growing rapidly. Moreover, "nearly a third of all sects (32 percent) reached their high-water mark on the day they began. Twenty-one percent of these sects began to decline in membership from their very first day. Another 11 percent have not grown since formation" (Stark and Bainbridge 1985, pp. 133-34). Relating these growth rates to the sects' levels of tension with society, Stark and Bainbridge (1985, p. 134) arrived at a conclusion that fits the rational choice model perfectly: "Many sects fail to grow (and are never transformed into churches) because their initial level of tension is so high as to cause their early social encapsulation. Once encapsulated, a sect may persist for centuries, depending on fertility and the ability to minimize defection, but it will rarely be able to recruit an outsider." 


\section{The Dynamics of Strictness}

The notion of optimal strictness becomes especially important in a changing social environment. To remain strong, a group must maintain a certain distance or tension between itself and society. But maintaining this "optimal gap" means walking a very fine line in adjusting to social change so as not to become too deviant, but not embracing change so fully as to lose all distinctiveness.

This principle appears to characterize the Mormon church's response to the change in women's roles from 1940 through 1987. Iannaccone and Miles's (1990) time-series analysis suggests that the Mormon church may have skirted the twin dangers of intransigence and loss of distinctiveness by a combination of initial resistance to social change followed ultimately by long-run accommodation. They conclude that "particularly in dynamic social environments churches must engage in a continuing balancing act, trading off between religious traditions and social norms. . . A certain amount of tension with secular society is essential to success-the trick is finding, and maintaining, the right amount."

No group illustrates this continuing balancing act more dramatically than the Amish. As Kraybill (1989a, 1989b) has shown, the Amish have, throughout this century, engaged in "a dynamic process of negotiation which enables them to retain their ethnic identity while simultaneously adapting to economic pressures. The negotiated compromises permit: the use of tractors at the barn but not in the fields, the hiring of cars and trucks but not ownership, the use of telephones in shops but not in homes, the use of modern farm machinery, if pulled by horses, ... and the use of hydraulic power in lieu of electricity" (Kraybill 1989b, p. 8). ${ }^{26}$ These examples of selective adaptation challenge our image of the rigid sect, dogmatically determined to resist change at all cost. Strategic, costbenefit calculations shape the "strange" practices of an extreme sect no less than they shape the "normal" practices of a mainstream church.

\section{Knowing Where to Give In}

A final extension to Kelley's thesis concerns the kinds of strict demands that benefit a church versus the kinds that backfire. Here the conclusion is straightforward: successful strictness must involve the sacrifice of external (nongroup) resources and opportunities that the group can itself re-

${ }^{26}$ This strategy appears to have been quite successful, since it has coincided with a growth rate far exceeding that of the Mennonites and the Brethren, two closely related Anabaptist groups that have followed much more assimilative courses (Kraybill $1989 b)$. 
place. In other words, a group can afford to prohibit or put out of reach only those "commodities" for which it offers a close substitute. Arbitrary strictness will fail just as surely as excessive strictness. Indeed, being strict about the "wrong" things will be perceived as "excessive" strictness. It is not hard to identify examples. Cults and communes that isolate themselves geographically, thereby depriving their members of the normal means of production, must provide an internal productive economy based on farming, manufacture and trade, or the like. Sects that isolate their members socially must provide alternative social networks with ample opportunities for interaction, friendship, and status.

Climbing out on a speculative limb, I would suggest that, in the last generation, the Catholic church in America has suffered from a failure to abide by this principle. I suspect that Kelley identifies only one-half of the problem when he attributes Catholic membership losses to the Vatican II reforms, whereby the church " 'leaped over the wall' to join the liberal, 'relevant,' ecumenical churches" (1986, pp. 33-35). The other half of the problem is found in its hard-line positions on birth control and priestly celibacy. The Catholic church may have managed to arrive at a remarkable, "worst of both worlds" position-discarding cherished distinctiveness in the areas of liturgy, theology, and lifestyle, while at the same time maintaining the very demands that its members and clergy are least willing to accept. ${ }^{27}$

\section{CONCLUSION}

The strength of strict churches is neither a historical coincidence nor a statistical artifact. Strictness reduces free riding. It screens out members who lack commitment and stimulates participation among those who remain. Rational choice theory thus explains the success of sects, cults, and conservative denominations without recourse to assumed abnormality, irrationality, or misinformation. The theory also predicts differences between strict and lenient groups, distinguishes between effective and counterproductive demands, and demonstrates the need to adapt strict demands in response to social change.

The rational choice theory of organizational strictness accounts for empirical regularities that have fascinated sociologists for most of a century. Mainstream churches and extremist sects emerge as analytically distinct modes of religious organization rather than as ad hoc descriptive categories. The empirical correlates of sectarianism are derived as formal

${ }^{27}$ This interpretation may help to harmonize the apparently divergent conclusions drawn by Kelley, who sees Vatican II as a costly sellout, and by Greeley (1985), who sees Humanae Vitae as inducing a widespread reduction in Catholic commitment. 
consequences of a sectarian strategy aimed at enhancing group commitment.

Survey data strongly confirm the theory's key predictions. Members of stricter denominations devote more time and money to their religions and are more likely to describe themselves as strong members of their faith. They socialize more extensively with fellow members and are less involved in secular organizations. They have, on the average, lower incomes and less education. The patterns hold across the full spectrum of denominations, Christian and Jewish.

Other predictions await further research and better data. A study of unsuccessful sects is needed to test the theory's prediction that too much strictness causes just as much harm as too little. A study of the content of sectarian demands would help test the prediction that successful groups must provide substitutes for the external rewards that they effectively prohibit. Results from studies like these might also indicate whether the rational choice model is more consistent with observation than models derived from alternative social-psychological assumptions.

Like Kelley's original study, this article has addressed the issue of church growth only indirectly. I have tended to assume that "strong" churches - churches with high rates of commitment, participation, and contributions - will find it much easier to achieve high rates of growth. This assumption certainly seems reasonable and is supported by empirical studies of church growth (Iannaccone et al. 1993). However, it blurs the distinction between necessary and sufficient. In commercial markets, the strongest firms are not always the fastest growing. Highly profitable businesses sometimes choose to maintain their current size and forgo an increased market share. The Amish have pursued an analogous strategy in the religious marketplace. The current, static version of the strict church model does not adequately address this distinction. A dynamic version is needed to clarify the relationship between the strength and growth.

Rational choice theories of religious behavior are new, provocative, and relatively undeveloped. This article has explored one such theory and has thereby sought to show how costly, apparently unproductive, demands can strengthen an organization and benefit its members. The relative ease with which it has integrated Kelley's strict church thesis, traditional church-sect typologies, and the basic features of American denominationalism suggests that further work is well worth the effort.

\section{APPENDIX}

An Example of Free Riding in Heterogeneous Populations

This appendix analyzes a simple, game-theoretic version of the model described in the body of this article. The population consists of two 


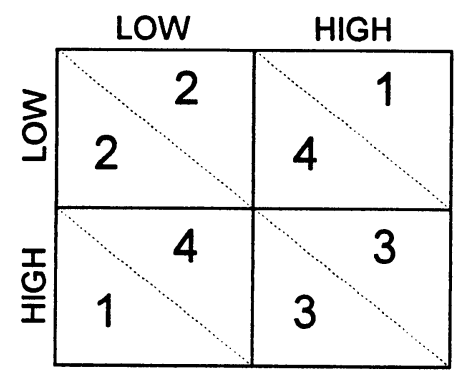

FIG. A1.-Both actors uncommitted

types of people, the religiously committed type $\mathrm{Cs}$ and the relatively uncommitted type Us. They make only two decisions: whether to join any given religious group and, contingent on joining, whether to maintain a high or a low level of participation. Each person acts rationally, choosing the group and level of personal participation that maximizes his or her welfare. Personal welfare depends on the person's own decisions and those of others. Specifically, each person's welfare rises when the other members of the group increase their participation levels. These assumptions capture the key features of the general model described in the body of the article. (Note that the model also accommodates a third type of person-type I, who is religiously indifferent or antagonistic. By definition, type I people derive no utility from religion. They will not join any religious group, and hence need not concern us further.)

Formal setup.-We may model the situation with a series of matrices that specify the payoffs that people receive from their actions and from those of others. (The specific payoffs are unimportant; only their relative magnitudes matter.) Figure A1 describes the possible outcomes in a group consisting solely of uncommitted, type U, people. For simplicity, imagine that the group consists of just two people whose participation levels are noted along the top and side of the matrix. (Essentially the same argument applies to groups of three or more. In that case, however, the matrix depicts the situation from a single member's perspective. His or her own participation level is listed along the top and those of the other members are listed along the side.) The cells of the matrix show the net payoffs accruing to each member contingent on the choices they both make. The number above the diagonal is the payoff to the member whose choice is listed on top, and the number below the diagonal is the net payoff to the member whose choice is listed on the side. For example, if both choose low levels of participation, they end up in the top left cell, and each earns a payoff of two. If both choose high levels of participation, they end up in the bottom right cell, and each earns a payoff of three. When the members choose different levels of participation (top right and 


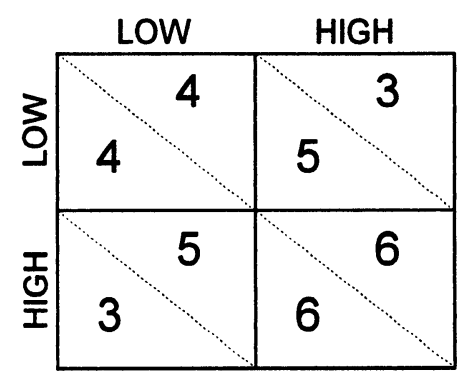

Fig. A2.-Both actors committed

bottom left), the member with the low level of participation earns a payoff of four (since he or she free rides off the other member's high participation without making a corresponding contribution), whereas the member with the high level of participation earns only one (since his or her costly involvement went unmatched). Taken as a whole, the choices yield the classic Prisoner's Dilemma, in which each member is tempted to free ride off the other. The temptation arises because, regardless of whether the first member chooses a high or low level of participation, the second member maximizes his or her personal payoff by choosing a low level. Hence, the group is likely to gravitate toward the top left cell, with low levels of participation, and low levels of reward, all around. This outcome becomes progressively more likely as the size of the group, and hence the difficulty of monitoring the others, increases.

The situation is different for the more committed, type $\mathrm{C}$ people. Their payoff matrix, depicted in figure A2, does not lead to a Prisoner's Dilemma. Here, a low level of participation is no longer the dominant strategy. Rather, as long as the first person maintains a high level of participation, the second does best by responding in kind. In other words, type $\mathrm{C}$ people are not tempted to free ride. They therefore are likely to end up in the bottom right cell, enjoying the benefits of a high-powered group.

Free riding. - Consider now the problems that arise when different types of people are able to mix. We have seen that a group consisting solely of type $\mathrm{C}$ people can maintain high levels of participation, and so be "strong," whereas a group of type U people tends toward low levels of participation, and so is "weak." (This result has nothing to do with differing levels of self-interest, rationality, or altruism among the two groups. Rather it depends entirely on the different costs and benefits they derive from group participation.) In practice, however, these two groups have difficulty existing side by side. The payoff structures are such that everyone prefers to be in groups where the other members maintain high levels of participation. Hence, type $U$ people will tend to migrate from 


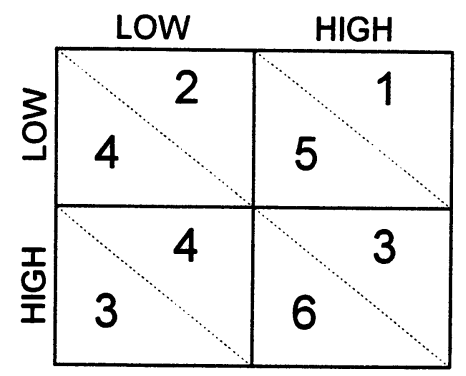

FIG. A3.-Mixed: committed actor is along the side; uncommitted actor is at the top.

the weak groups to strong ones. (The migration cannot be prevented unless it is possible to ascertain people's true character or to accurately monitor their actual level of participation.) The resulting mixed groups will have payoff structures like those in figure A3. In this matrix, which depicts the decisions of a type $U$ person along the top and the decisions of a type $\mathrm{C}$ person along the side, the payoffs above the diagonal come from figure A1 and the payoffs below the diagonal come from figure A2. Examining the payoffs, we find that the type $U$ person has the same unconditional incentive to free ride as in figure A1. But if the type $\mathrm{U}$ person maintains a low level of participation, the type $\mathrm{C}$ person has no incentive to do otherwise. Hence, the presence of type $\mathrm{U}$ people undermines what would otherwise be a strong group of type $\mathrm{C}$ people. The less committed people free ride, holding back resources of time, energy, and so forth from the group. And, faced with this free riding, even the committed members find it no longer worth their bother to participate fully (because their contributions to the group are effectively "stolen" by free riders). The situation therefore tends to degenerate until no one is participating fully. This result is inefficient because the type Cs end up worse off than before (earning a payoff of four rather than six) whereas the type Us end up no better off (since they earn two either way). Free riding has made all groups weak.

A costly solution.-Figure A4 shows how seemingly gratuitous costs can mitigate the free-rider problem found in matrix A3. The cost consists of a uniform one-unit membership penalty. Members pay the penalty regardless of their participation level. Hence, all payoffs are one less than in the original mixed-group matrix, A3. If uncommitted people join this group they will make it just as weak as any of the others they join (since low participation is still their dominant strategy), but having done so they will find themselves in the top left cell earning a one-unit payoff (their standard two-unit payoff minus the one-unit membership cost). Since this one-unit payoff is less than they earn in a standard weak group, 


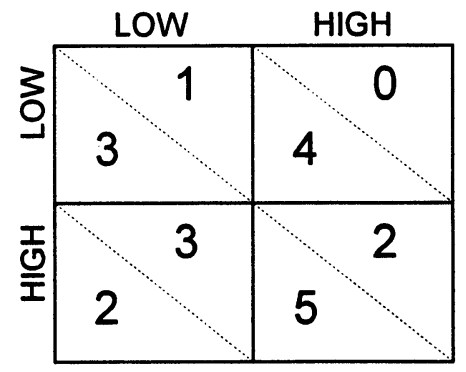

FIG. A4.-Mixed group with one-unit membership cost

such as those depicted in figures A1 or A3, they will forsake the costly group, leaving it to the committed people. But once the Us leave, the Cs will find that they have a viable, albeit costly, strong group, in which all the payoffs are just one unit less than those in the (unobtainable) matrix A2. The Cs will therefore maintain high levels of participation and earn a five-unit payoff. To complete the proof, note that even after the group becomes strong, type $U$ people still have no incentive to rejoin, since the best they can do is no better than the two-unit payoff that they earn in matrix A1.

Apparently gratuitous costs can thus divert uncommitted people from strong groups. Committed people end up forming costly groups, while the less committed people end up in standard groups, and the free riding that otherwise undermines all groups is mitigated. The problem and its apparently bizarre solution both arise as consequences of rational self-interest.

\section{REFERENCES}

Allen, Douglas W. 1990. "An Inquiry into the State's Role in Marriage." Journal of Economic Behavior and Organization 13:171-91.

Bainbridge, William Sims. 1982. "Shaker Demographics, 1840-19010: An Example of the Use of U.S. Census Enumeration Schedules." Journal for the Scientific Study of Religion 21:352-65.

Beck, Scott H., Bettie S. Cole, and Judith A. Hammond. 1991. "Religious Heritage and Premarital Sex: Evidence from a National Sample of Young Adults." Journal for the Scientific Study of Religion 30 (2): 173-80.

Cochran, John K., Leonard Beeghley, and E. Wilbur Bock. 1988. "Religiosity and Alcohol Behavior: An Exploration of Reference Group Theory." Sociological Forum 3 (2): 256-76.

Donahue, Michael J. 1991. "Prevalence of New Age Beliefs in Six Protestant Denominations." Paper presented at the meeting of the Society for the Scientific Study of Religion, Pittsburgh.

Douglas, Mary. 1986. How Institutions Think. Syracuse, N.Y.: Syracuse University Press.

Eister, Allan W. 1967. "Toward a Radical Critique of Church-Sect Typologizing: 


\section{American Journal of Sociology}

Comment on 'Some Critical Observations on the Church-Sect Dimension.' " Journal for the Scientific Study of Religion 6:85-90.

Finke, Roger, and Rodney Stark. 1988. "Religious Economies and Sacred Canopies: Religious Mobilization in American Cities, 1906." American Sociological Review 53:41-49.

1992. The Churching of America, 1776-1990: Winners and Losers in America's Religious Economy. New Brunswick, N.J.: Rutgers University Press.

Goldstein, Sidney, and Barry Kosmin. 1991. "Religious and Ethnic Self-Identification in the United States, 1989-90: A Case Study of the Jewish Population." Paper presented at the annual meeting of the Population Association of America, Washington, D.C.

Greeley, Andrew M. 1985. American Catholics since the Council, an Unauthorized Report. Chicago: Thomas Moore Press.

Greene, William H. 1990. Econometric Analysis. New York: Macmillan.

Hall, John R. 1988. "Social Organization and Pathways of Commitment: Types of Communal Groups, Rational Choice Theory, and the Kanter Thesis." American Sociological Review 53:679-92.

Hechter, Michael. 1987. Principles of Group Solidarity. Berkeley and Los Angeles: University of California Press.

Hines, Robert V. 1983. California's Utopian Colonies. Berkeley and Los Angeles: University of California Press.

Hoge, Dean R. 1979. "A Test of Denominational Growth and Decline." Pp. 179-97 in Understanding Church Growth and Decline: 1950-1978, edited by Dean R. Hoge and David A. Roozen. New York: Pilgrim Press.

Hoge, Dean R., and David A. Roozen. 1979. Technical Appendix to Understanding Church Growth and Decline, 1950-1978. Hartford, Conn.: Hartford Seminary Foundation.

Iannaccone, Laurence R. 1988. "A Formal Model of Church and Sect." American Journal of Sociology 94:S241-S268. 1992a. "Religious Markets and the Economics of Religion." Social Compass 39 (1): $123-31$.

. 1992b. "Sacrifice and Stigma: Reducing Free Riding in Cults, Communes, and Other Collectives." Journal of Political Economy 100 (2): 271-91.

. In press. "Risk, Rationality, and Religious Portfolios." Economic Inquiry.

Iannaccone, Laurence R., and Carrie A. Miles. 1990. "Dealing with Social Change: The Mormon Church's Response to Change in Women's Roles." Social Forces 68 (4): 1231-50.

Iannaccone, Laurence R., Rodney Stark, and Daniel V. A. Olson. 1993. "Religious Resources and Church Growth." Paper presented at the meetings of the Society for the Scientific Study of Religion, Raleigh, N.C.

Johnson, Benton. 1963. "On Church and Sect." American Sociological Review 28: 539-49.

. 1971. "Church and Sect Revisited." Journal for the Scientific Study of Religion 10:124-37.

Kanter, Rosabeth M. 1973. Commitment and Community: Communes and Utopias in Sociological Perspective. Cambridge, Mass.: Harvard University Press.

Kelley, Dean M. (1972) 1986. Why Conservative Churches Are Growing: A Study in the Sociology of Religion. Macon, Ga.: Mercer University Press.

- 1979. "Is Religion a Dependent Variable?" Pp. 334-43 in Understanding Church Growth and Decline, 1950-1978, edited by Dean R. Hoge and David A. Roozen. New York: Pilgrim Press.

Kraybill, Donald B. 1989a. The Riddle of Amish Culture. Baltimore: Johns Hopkins University Press. 
1989b. "Amish, Mennonites, and Brethren in the Quandry of Modernity, 1880-1980." Paper presented at the Society for the Scientific Study of Religion, Salt Lake City.

Lawrence, Bruce B. 1989. Defenders of God. San Francisco: Harper \& Row.

Lazerwitz, Bernard, and Michael Harrison. 1979. "American Jewish Denominations: A Social and Religious Profile." American Sociological Review 44:656-66.

Lofland, John. 1977. Doomsday Cult. New York: Wiley.

Olson, Mancur. 1965. The Logic of Collective Action: Public Goods and the Theory of Groups. Cambridge, Mass: Harvard University Press.

Robbins, Thomas. 1988. Cults, Converts, and Charisma. London: Sage.

Roberts, Keith A. 1984. Religion in Sociological Perspective. Homewood, Ill.: Dorsey.

Roof, Wade Clark, and William McKinney. 1987. American Mainline Religion. New Brunswick, N.J.: Rutgers University Press.

Singh, Kushwant. 1953. The Sikhs. London: Allen \& Unwin.

Stark, Rodney. 1984. "The Rise of a New World Faith." Review of Religious Research 26:18-27.

Stark, Rodney, and William Sims Bainbridge. 1985. The Future of Religion. Berkeley and Los Angeles: University of California Press.

Stark, Rodney, and Charles Y. Glock. 1968. American Piety. Berkeley: University of California Press.

Smith, Adam. (1776) 1965. An Inquiry into the Nature and Causes of the Wealth of Nations. New York: Modern Library.

Tamney, Joseph B., Barbara A. Bunch, Paul R. Stieber, and Deborah L. Zigler-Geis. 1991. "The New Age in Middletown: An Exploratory Study." Paper presented at the meeting of the Society for the Scientific Study of Religion, Pittsburgh.

Warner, R. Stephen. 1993. "Work in Progress toward a New Paradigm for the Sociological Study of Religion in the United States." American Journal of Sociology 98:1044-93.

Weber, Max. (1904-5) 1958. The Protestant Ethic and the Spirit of Capitalism, translated by Talcott Parsons. New York: Free Press.

- (1922) 1963. The Sociology of Religion, translated by Ephraim Fischoff. Boston: Beacon. 